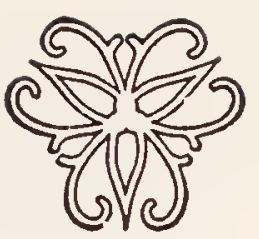

\title{
THE IMPORTANCE OF LANGUAGE
}


Digitized by the Internet Archive in 2018 with funding from Kahle/Austin Foundation

https://archive.org/details/importanceoflang0000blac 


\section{THE IMPORTANCE OF LANGUAGE}

edited by Max Black

Cornell Paperbacks Cornell University Press

Ithaca and London 
(C) 1962 by Prentice-Hall, Inc., Englewood Cliffs, N.J.

Copyright assigned 1968 to Max Black

All rights reserved. Except for brief quotations in a review, this book, or parts thereof, must not be reproduced in any form without permission in writing from the publisher. For information address Cornell University Press, 124 Roberts Place, Ithaca, New York 14850.

First published 1962

First printing, Cornell Paperbacks, 1969

Third printing, 1982

Published in the United Kingdom by Cornell University Press Ltd., Ely House, 37 Dover Street, London W1X 4HQ

International Standard Book Number 0-8014-9077-4

Library of Congress Catalog Card Number 62-13720

Printed in the United States of America

The paper in this book is acid-free, and meets the guidelines for permanence and durability of the Committee on Production Guidelines for Book Longevity of the Council on Library Resources. 